\title{
Space in the 20th Century Theatre: 1. Theatre and Architecture
}

\author{
Radivoje Dinulović \\ University of Novi Sad, Faculty of Technical Sciences, Chair in Art Applied to Architecture, Serbia
} \begin{abstract}
Citation: Dinulović R. Space in the 20th Century Theatre: 1 .
Theatre and Architecture. SEE J Archit Des. 2015 Nov 11;2015: 10006. http://dx.doi.org/10.3889/seejad.2015.10006

Key words: 20th Century theatre; theatre and architecture; theatre in the typology of architectural objects; theatre as a programme in architecture; theatre as an art form.
porrespong

'Correspondence: Prof. Dr. Radivoje Dinulović, University of Novi Sad, Faculty of Technica Scionces, Chair in Ant Applied to Novi Sad, Faculty of Technical Sciences, Chair in Art Applied
Architecture., Serbia. E-mail: radivoje.dinulovic@gmail.com Received: 06-Oct-2014; Revised: 20-Oct-2014; Accepted:
26-Oct-2015; Published: 11-Nov-2015

Copyright: ๑ 2015 Radivoje Dinulović. This is an openaccess article distributed under the terms of the Creative distribution, and reproduction in any medium, provided the original author and source are credited.

Competing Interests: The author have declared that no competing interests exist.
\end{abstract}

\begin{abstract}
AIM: The aim of this study is to present the state of the theatre and architecture as a part of Space in the 20th Century Theatre.

MATERIAL AND METHODS: Three aspects of the architecture were described: theatre in the typology of architectural objects, theatre as a programme in architecture, and theatre as an art form.

RESULTS: Theatre has never been, nor could it ever become a subject independent of architecture. Correspondingly, the stage space is not, and should not be a separate issue, the subject of "consultants", but a crucial and equally worthy part of the complex, rich and consistent structure of the theatre house - as a whole. The theatre house in its entirety becomes a public facility and begins to develop its central function in the city. From this point of view, it is not only that the theatre has not lost its traditionally dominant urban position, on the contrary, that position is constantly evolving.

CONCLUSIONS: Theatre, based on interpersonal communications in real space and real time, provoking our experiences on the borderline between reality and illusion, and constantly questioning those boundaries, can possibly discover the "otherness of the real world", that is to "change the nature of the individual, in order to change the essence of the world".
\end{abstract}

\section{Theatre in the typology of architectural objects}

Among many types of architectural objects, theatres have a distinct place. Or is it just our understanding - we might even say a preconception, which arises from contemplating about multifaceted spiritual and architectural programme of these edifices, their complex functional and technological structure, urban, social, and even ideological function. However, through in-depth research and evaluation of the contribution that theatre architecture has given to the very phenomenon of theatre on one side, and the place and the role of theatre structures in the history of architecture on the other side, we will come to very different conclusions.

The venues where scene events are to be performed in the modern era which almost coincides with the $20^{\text {th }}$ Century, from Antoine to Stanislavski, Appia, Craig, Reinhardt, Copeau, Meyerhold or
Brecht, till Brook, Schechner, Schumann, Grotowski, and Stein - is one of the basic themes of revising the construction of theatre. Nevertheless, the configuration of the stage and the auditorium, as the key point of theatre architecture, in almost all objects designed and built specifically for theatrical performances, is still based on one of tree conventions - baroque, Elizabethan or functionalistic. The conventions in theatre are without a doubt one of the core assumptions that this artistic phenomenon is based upon. During the development of theatre, several independent systems of conventions have emerged, which were different in type and levels of complexity, and which are used as a base for creating and read the theatrical act. There is a particular topic of systems of conventions for reading of stage spaces and stage changes. Besides the two traditional (Baroque and Elizabethan) systems of conventions, in the twentieth century a functionalist system of conventions has been established, based in part on the various conventions of theatre of the Far East. Here, the stage itself, its structure, physical 
organisation and character, as well as artistic and technical means of theatre play (scene changes, lighting, sound, movement ...) become semantic treasure in itself, a special model of the theatre being based almost exclusively on the demand for perfect functioning of all of the above (one might say, even the formal) manifestations of theatrical events. Transformations of conventional spatial models in contemporary theatre architecture are primarily a result of development of technical and technological resources and systems, their impact on the size, character and structure of space - first and foremost the space of the stage, and the auditorium.

At the same time, architectural significance and the character of modern purpose-built theatre houses as a whole have not had much influence on the ideas, concepts, character, or even the artistic methods of modern theatre. It is understood that, when I am deliberating on the subject of houses designed and built for the purpose of housing theatre performances, I am not discoursing on the subject of so-called environmental theatre, nor am I talking about reconstructions and reutilizations of various "secular" spaces (railway and fire stations, warehouses, fairs and factory halls, power plants, and even abandoned churches), or the phenomena of theatralisation of the city, and the urbanisation of spectacles. All the while I do not question the impact (which is at present-day at some places even crucial) of these phenomena on the theatre, on architecture, and on the city itself. This topic has been specifically addressed at the cycle of international symposia entitled "The spectacle - City - Identity" organised by YUSTAT, since 1996 till the year 2000. The papers were published under the same title (YUSTAT, 1998) and in the book "Urban Spectacle" (YUSTAT and Clio, 2000) [1].

In view of that, the significance of theatres in the history and development of modern and particularly contemporary architecture has been unrecognised and marginalised. In history books, encyclopaedias, and problem-oriented studies of contemporary architecture theatre facilities are barely mentioned. So Kenneth Frampton in his Modern architecture, among hundreds of examples (336 illustrated) mentions seven theatres [2], Alberto Lampugnani in his Encyclopaedia of 20th Century Architecture presents some 500 objects, including 12 theatres [3], Charles Jenks in the Modern Movements in Architecture analyses three [4], and in the Language of postmodern Architecture he analyses two examples [5]; out of 441 illustrations in William J. Curtis's Modern Architecture five are theatres [6], as well as in A Short History of Western Architecture by R. Furneaux Jordan (out of 432 illustrations) [7]. Ranko Radovic has included in his Contemporary Architecture examples of eight theatres out of 490 illustrated examples, of which at least three with an ironic attitude [8]. This phenomenon does not belong only to contemporary architecture, which is confirmed in the referent History of Architecture by Sir Banister Fletcher in which among the thousands of (unnumbered) illustrations on 1621 page of text a total of 19 theatres can be seen [9]. The undisputable architectural value and significance of several outstanding buildings, such as the theatre in Cologne by Henry Van de Velde, Sydney Opera House by Jørn Utzon or the buildings in New York's Lincoln Centre by Eero Saarinen, Max Abramowitz, and Philip Johnson, is not at all based on the programme or functionality of the technology of theatres themselves, and even the ideas of theatre and the ideas of architecture of a theatre building, are set as entirely independent issues. The Glyndebourne Opera House by Michael Hopkins is the latest and, I believe, the most prominent example of that point.

Almost a century long reality has unambiguously confirmed the words of György Lukács from 1911 that the drama and stage have been separated from each other, and that "true new theatre exists only as an ideal, just as something that should be, but is not attainable" [10]. At the same time, the theatre "of our time, in which rather diverse categories of education of human conciseness can dwell" [11] as an idea and the program, continuously draws attention of students and young architects, being the subject of numerous graduate theses, studies, and open competitions. It seems that the "dream of a new stage" is practically non-existent in institutional theatre (and theatre buildings are built only for institutional theatres), while the architecture becomes an issue only when the subject of theatre space becomes the subject of ideas, research and theoretical discussions. In our locale, perhaps due to the fact that in the twentieth century in Serbia only four new theatre houses were built (National Theatre of Moravia region in Niš by Vsevolod Tatarinov, 1939; The National Theatre of Užice by Stanko Mandić, 1962; Atelier 212 in Belgrade by Bojan Stupica, 1964; and the Serbian National Theatre in Novi Sad by Viktor Jackiewicz, 1981), this issue has for decades enticed special interest.

Project which has had, without a doubt, a most profound influence on thought, design and construction of contemporary architectural works designed for scene events, was the Totaltheater by Walter Gropius and Erwin Piscator from 1927, even if it was actually never built. This case, as do many others, proves once again that there is great significance and purpose in creating "paper architecture" [12], which is often more inspiring and created with more thought than the houses that were actually built. However, we can find a more significant paradigmatic phenomenon in the fact that the central theme of this project is the variable configuration and the active role of stage-auditorium space, the technology serving the stage and the plays, but not all the other programme questions of architecture 
(utilitarian and functional technology of the facility, morphological structure of the house, architectural language, attitude toward the urban context ...). Whilst talking about structure, I always have in mind the term „which simultaneously defines the entirety, parts of that entirety and the relations between those parts" [13]. It becomes clear at this point, and it will be confirmed many times in the future, that the modern theatre unravels the theme of relationship between drama and the space in which the drama will be performed, but it omits, it does not even notice, the issue of the house as a whole.

lain Mackintosh, who is at present day probably the most influential theatre consultant, without whom theatres virtually cannot be built in the UK, speaks about all this most directly in his highly acclaimed book: "Architecture, Actor and Audience". In his work Mackintosh explores the "contribution of theatre architecture to the theatre experience" stressing that the "theatre architecture is one of the most vital ingredients of the theatrical experience" and, simultaneously, "one of the least understood." But Mackintosh decides not to deliberate on facades, entrances, foyers, halls and even the spaces behind the stage, since, as he says, there are so many textbooks for architects and technicians who want to learn "how to plan those vitally important but essentially secondary spaces" [14]. Of course, the thesis of "serviced" and "serving" area is not new, but it is highly hazardous to introduce it in theatre, a place of synthesis and "equality at work" [15], and thus further promote the already proverbially fragmented and almost autistic access to individual areas, domains and specialties. Louis Kahn's partitioning of space by the criteria of which are "serving" which are "being served" is mentioned on page 132nd of Ranko Radovic's book Contemporary Architecture (Faculty of Engineering - Stylos, Novi Sad, 1998) [16]. For more information on ideas of Louis Kahn see the records of his lectures, published in Richard Saul Wurman's newsroom entitled "What Will Be Has Always Been" (University of Pennsylvania, Harrisburg, 1986) [17]. Theatre has never been, nor could it ever become a subject independent of architecture. Correspondingly, the stage space is not, and should not be a separate issue, the subject of "consultants", but a crucial and equally worthy part of the complex, rich and consistent structure of the theatre house - as a whole. Rare, but significant examples of that are the works of Ledoux, Poelzig, Melnikov, Rossi or Stupica, and they clearly suggest that the synthesis of all aspects of theatre and architecture is not only possible but also necessary.

\section{Theatre as a programme in architecture}

The architectural programme of a theatre as a complex spiritual product is one of the most inspiring subjects for the research of venues, and designing structures for the spectacles in general. The main consideration of programme deliberations is the term of theatre itself which "simultaneously denominates theatrical art, the place where the performances are held, and the social act of attending the performance" [18], as well as the challenging impossibility of unambiguously defining contemporary theatre. The fact "that there is no theatre of our time, there are different theatres which due to circumstance exist at the same time and space" [19] and the contradiction between the almost daily volatility of theatre as an art form and the permanence of theatre buildings, puts an architect in a position to independently and almost autonomously anticipate the content, character, logic, expression, and the means of theatre for which he is designing space. In that way the architect is called upon to answer questions which in our epoch, as in the preceding, he is not and could not be sufficiently apt for. The irony is that, on the other hand, architecture "is one of the human activities which has a supreme effect on the quality of life" [20], and the architect, by nature of his calling, tends to make decisions that, strictly speaking, do not belong within the domain of his contemplation. This desire was expressed in almost every architectural project, and may be subject to separate studies in various typological units and series. Among the most impressive examples of the buildings and complexes for living in "special circumstances" - homes for children and the elderly, special hospitals and sanatoriums, barracks, prisons. Even further, controlled residential areas (ghettos), refugees, prison, penitentiary, and concentration camps - which were, unfortunately, also the works of architects. In the context of our work, there is a particularly interesting example of the fortress Terezin (Terezín; Theresienstadt) in the Czech Republic, where the Nazi government in 1941, and 1942 deported of the entire population of a small town (see the Encyclopaedia Britannica, CD-Rom edition, 2001) [21], in order to organize the life of the Jewish ghetto. This town has, in fact, been like a great theatrical performance, in which the German authorities toward Jews was portrayed the Red Cross delegation. It seems to me that this is crucial for the focus and interest that architects lend to the field of theatre, all the while being the key reason for their rather limited range. The exceptions are the great reformers of architectural thought in general (Ledoux, Schinkel), authors who belong to the artistic movements at the same time grounded in the theatre and architecture (Melnikov, Gropius), the architects whose sensibilities and expression are driven by theatre and theatricality (Rossi), or those who belong to architecture as well as to theatre (Jouvet, Stupica).

All the while we must keep in mind that the presentation of theatrical performances is the most significant, but by no means the only functional or technological process of the theatre as a building, or even as an institution. Programme in the theatre 
includes a long and complex series of various functional processes and procedures, each closely linked and intertwined, which, in principle, take place in domains of artistic, technical and operational preparations, production and enactment of stage events. When I speak of theatre as a cultural institution, I infer that it contains all these functional and technological lines. Of course, their character and dimensions vary greatly, but in terms of quality and procedure, these processes can be viewed as fixed categories.

In terms of functional and technological processes and, after all, the theatre in general, dual nature of theatre and theatrical space is a permanent framework of thought, analysis and research. The "fourth wall convention" that divides the space of dramatic enactment from the space where it can be viewed from, physically and spiritually extends far beyond the stage and auditorium. "The task of the theatre architecture is to find the most ideal combination of space, actor's movement and speech, and the one area which must include the viewer. The viewer's space has in turn its own requirements. It must be determined by the number of spectators and must provide them with the contact with the actor that is as close as possible. The viewer still must not interfere with the actor. Particular sphere of the actor representative presentation must not be violated. The main problem of theatre architecture lies in the particular requirement of seeking the presence and absence of spectators. The actor must be completely free in his movements. It is indeed moving for the sake of the viewer, but as if the viewer does not exist" [22]. One could speak of two arrays of programmes, functions and spaces, which have their own independent lives in temporal and spatial sense, and which are inevitably joined and united in the architectural configuration of the theatre hall and stage. The issue of a possible encounter of worlds in front of and behind the scenes, beyond the space or time of the enactment of the play, is a special one, and not a novelty. The obsessive need of the audience to make physical contact with the actors (and probably the need for their demystification) is easy to recognise through the extraordinary popularity of theatre lounges and cafés next to the theatre, which can also be understood as a special form of stage.

These phenomena, as well as the altered concepts of financing theatre, are the bases of the tendency to include various commercial programs cafes, restaurants, bookstores, galleries, libraries and information centres, educational units, tourist points into the part of the building intended for audience, which then becomes active during the entire day, and the theatre a venue develops into a form of a cultural centre. With the development and popularisation of stage technologies, as well as the expansion of educational programs and institutions dealing with this field, and finally with the radical intensification of the influence of marketing and management in the arts - a complex of technical and administrative spaces behind the scenes also receives a public profile. Thus the theatre house in its entirety becomes a public facility and begins to develop its central function in the city. From this point of view, it is not only that the theatre has not lost its traditionally dominant urban position, on the contrary, that position is constantly evolving. Examples like the complex of the National Theatre in London, or Lincoln Centre in New York, bear witness to it.

\section{Theatre as an art form}

Theatre is "a complex art, which contains elements of all other arts, namely literature, music, painting, sculpting, architecture, and art of acting, which is not derived from any other art form, but is a specific feature of the theatre" [18]. Under the term "theatre" understood in terms of enactment of plays, I infer every arranged stage event based on a dramatic peace, which can be considered as a whole in terms of content and meaning, and where artists and viewers tend to share catharsis [Catharsis (kóoapoıs) is the basic mean of emotional purification which is created in the viewer through „evoking empathy and fear" (Aristoteles, Art of Poetry)] [23] through mutual communication, as a "call to man in its totality" [24].

Viewed etymologically, the term "theatre" is derived from the Greek verb "watch", but refers to the phenomena addressed to the senses of seeing and hearing. Branko Gavela claimed that theatre is a form of artistic communication carried out by optical and acoustic means, which invites in viewers parallel psychophysical phenomena as a source of extraordinary emotional and cognitive experience. "We do not conceive the actor by listening and watching him. Listening and watching are only means of conveyance, we conceive the actor by employing in ourselves simultaneously with his actions all those organic elements, which in real life are the companions and regulators of these actions" [22]. Theatre, therefore, is not "a play for watching" (Schauspiel), nor is it "a play for hearing" (Hörspiel), but it is a joined play "omniplay" (Mitspiel), a complex phenomenon in which individual elements are lost, as evidenced by numerous intersections of meanings and the origin of words, such as the arena and the auditorium, for example.

The spectator, for whom an actor acts in a play, though an individual, is actually by definition a collective phenomenon, "plural phenomenon", not "accidentally quantitative", but "plural by principle". An actor in a theatre play does not act for specific, individual viewers, but for the "collective viewer". The 
viewer, whom the theatrical performance itself will form, will not experience watching of a particular actor, but a new view of himself. "It will happen through the actor, and this process within the viewer requires the spatial separation of viewer and actor, finding the space that will best facilitate the experience of a viewer" [22]. In that way the theatre puts the viewer in a spiritually active position. That, ultimately, means realisation of itself through the introspective process of searching for the core values of existence. In this quite unique property of theatre, that the viewer in it always becomes a participant, lays the greatest value and importance of this artistic phenomenon.

If we look at the theatre for an anthropological point of view, then it can be defined as "the art of transformation into another being" [18], whilst the very concept of transformation becomes the issue of new definitions, referring not only to performers, but also to the spectators. Speaking of classic dramatic composition and the creation of dramatic tension, "prolonged strain which leads the viewer into a state of agitated anticipation of the end" [25], as well as its basic assumptions, even Aristotle considered the importance of the viewer, "his ability to watch and listen" [23] and be influenced by the drama, "ultimately brought even to the ideal consequence - the transformation of the viewer" [25].

The language of theatre has been defined by Tadeusz Kowzan, in accordance to Lessing's classification of arts to those that appear in space and those that occur in time (theatre being the one that incorporates both categories), as a system of thirteen different types of signs. Some elements of this language belong to communication in time (play, music ...), others are parts of communication in space (setting, costume, lighting ...), and the third set of elements are those that synthesise both fields, and are characteristic only of theatre, such as movement. Speaking of movement we are in fact considering an action that is intentional and consciously made (in theatre every movement, as a principle, is deliberate and conscious). Enactment of a play is a central concern of the theatre audience; the enacting is structured according to certain rules of composing a play with the aim of maintaining dramatic tension. Orientation toward action is explained by Demarsy [26] as through the traditional existence of diachronic perception, where for the viewer everything that is happening on stage is a function of what is going to happen on stage.

Although the theatre was created by transforming religious rituals in the early communities, and "it bears in itself as a rudiment not only its sensationalism", but also its "religious, ceremonial potency" [10], it is separated from the rituals and defined as a specific form of artistic, spiritual and social communication. For the distinction from the ritual and for establishing theatre, three basic elements are required: "speech or singing by the actors, regardless of the original choir singing in unison; element of conflict within the dialogue; and viewers emotionally involved in the action in which do not participate" [27]. Theatre could, on that basis, be seen through a new triad: the system of resources that make the theatrical language of communication; artistic content created in response to the need to express through theatrical means, which is the subject of this communication; and the reasons for the existence of theatre as a social phenomenon, that is the answer to society's needs for the theatre. In other words, the theatre is defined by answers to the questions: how it operates, what constitutes it and why does it exist.

The largest number of theoretical and philosophical assumptions about the purpose and function of theatrical art, from Aristotle to present day, is based on the understanding that theatre is oriented toward social elite. In these theories popular theatre, as opposed to art theatre, is seen as a form of mass entertainment. "Art is by nature aristocratic, and naturally selective in its effect on the audience. For even in its collective manifestations, like theatre and cinema, its effect is bound up with the intimate emotions of each person that comes to contact with the work" [28]. "Maybe it is not too paradoxical to say that in the intellectual activities which are driven by most democratic intentions (teaching, moralizing) reside more aristocratic elements (by means of emphasis, though often unconsciously, on spiritual difference between the creator and particular recipients), than there are in the most aristocratic, mystical ceremony" [10].

Correspondingly, the history of modern drama and modern theatre, or rather the complex and diverse structure of movements, schools, groups and authors in the theatre of the twentieth century, is the history of looking for the answer to the question of a social function and position of the theatre. "Is there, is modern drama possible: what does that question mean? Generally speaking: do the external circumstances offered by modern life allow the emergence of theatre and what might theatre be like? The question is: Are there such phenomena of social life, arising from modern life, which are suitable for expression in dramatic form, or which possibly directly require dramatic form as their perfect mode of expression?" [10].

Today "the word theatre has many meanings which are not distinct enough. In most of the world, the theatre has no exact place within the society, no clear purpose, it only exists in fragments: one theatre chases money, another chases glory, another chases emotion, another chases politics, another chases fun" [24]. Tarkovsky wrote that it is not the role of art, not even the theatre, to teach, spread ideas, develop thinking, or to serve as an example. "It is obvious that art cannot teach anyone anything, since in four thousand years humanity has learnt nothing at all ... Art only has the capacity, through shock and 
catharsis, to make the human soul receptive to good" [28]. And the theatre, based on interpersonal communications in real space and real time, provoking our experiences on the borderline between reality and illusion, and constantly questioning those boundaries, can possibly discover the "otherness of the real world" [29], that is to "change the nature of the individual, in order to change the essence of the world" [30]. Drama, for which the "mythical rebuttal of the discomfort of death" [31] is a hypothesis, uses "a symbolic image of the tragic death which can evoke the meaning of life" [32]. In a world without God, says Derrida, "only death can be a total theatre, a death that is by the logic of life the only real theatre" [33].

\section{References}

1. Dragićević-Šešić M, Šentevska I, Eds. Urbani spektakl, Beograd: Clio, Yustat, 2000.

2. Frampton K. Modern Architecture: A Critical History. Thames \& Hudson, 2007.

3. Lampugnani VM, Bergdoll B, Hatje G, Pehnt W. Thames and Hudson Encyclopaedia of Twentieth Century Architecture. Thames and Hudson, 1986.

4. Jencks C. Modern Movements in Architecture. Penguin Books, 1987.

5. Jencks C. The Language of Post-modern Architecture. Random House Incorporated 1991.

6. Curtis WJR. Modern Architecture since 1900. Prentice Hall, 1996.

7. Jordan RF. Western Architecture: A Concise History. Thames \& Hudson, 1985.

8. Radović R. Savremena arhitektura: između stalnosti i promjena ideja i oblika. Fakulte tehničkih nauka, 2001

9. Fletcher B. A History of Architecture: On the Comparative Method. Athlone Press, 1961.
10. Lukács G. History of Modern Drama. Nolit: Belgrade, 1978.

11. Bihalji-Merin O. The Builders of Modern Thought. Prosveta: Belgrade, 1965:pp. 302.

12. Radović $R$, in the preface of a book by Jakob Chernikov. The constructions of Architectural and Mechanical Forms. Građevinska knjiga: Belgrade, 1989:pp. 8.

13. Eco U. Culture, Information, Communication. Nolit: Belgrade, 1973:pp. 274.

14. Macintosh I. Architecture, Actor and Audience. Routledge: London, 1993: pp. 2-3.

15. Crnjanski M. The former theatre. 1924.

16. Radovic R. Contemporary Architecture. Faculty of Engineering - Stylos: Novi Sad 1998.

17. Wurman RS. What Will Be Has Always Been: The Words of Louis I. Kahn. HarperCollins Publishers, Apr 1, 1986

18. Dictionary of Literary Terms, Nolit: Belgrade, 1986

19. Selenić S, in the preface of Samuel Beckett drama Waiting for Godot. Nolit: Belgrade, 1985: pp. 7.

20. Mijić M. Acoustics in Architecture. Nauka: Belgrade, 2001: pp. 19.

21. Encyclopedia Britannica 2001: deluxe CD edition. Encyclopaedia Britannica, Incorporated, Sep 1, 2000.

22. Gavela B. Actor and Theatre. Sterijino pozorje: Novi Sad, 1967.

23. Aristotle. Art of Poetry. Zavod za izdavanje udžbenika: Belgrade, 1966.

24. Brook P. Empty Space. Lapis: Belgrade, 1995: pp. 146

25. Miočinović M. Modern Theory of Drama. Nolit: Belgrade, 1981.

26. Demarcy R. Eléments d'une sociologie du spectacle, Union générale d'édition, Paris, 1973.

27. Hartnoll P. The Theatre. Thames and Hudson: London, 1985.

28. Tarkovsky A. Sculpting in Time. Anonim: Beograd, 1999.

29. Pleša $B$ at the international siposium Stage design at the end of the 20th Century which was held within the Sterijino pozorje festival in 1998 (information about the symposium can be found in the text by Jovan Ljustanovic Virtual actor and the essence of theatre in the magazine Scene, no. 4-5, 1998, pp 74).

30. Selenić $S$ in the preface of the book Towards postmodern theatre. Institut za pozorište, film, radio i televiziju: Belgrade, 1992.

31. Barthes R. Light in the Dark Room. Rad: Beograd, 1981: pp. 33.

32. Gavela B, Novosti. Zagreb, br. 30, 29. I 1941: pp. 18

33. Derrida J. La scrittura e la differenza. Einaudi: Torino, 1971: pp. 294. 